\title{
Ombuds Institutions, Good Governance and the International Human Rights System
}

\author{
Second Revised Edition \\ Author: Linda C. Reif
}

This book uses comparative law and comparative international law approaches to explore the role of human rights ombuds, classic-based ombuds and other types of ombuds institutions in human rights protection and promotion, their methods of application of international and domestic human rights law and their roles in strengthening good governance. It highlights the increasing importance of national human rights ombuds institutions globally and their roles as national human rights institutions (NHRIs).

Chapters address: ombuds institutions as mechanisms to strengthen democratic, horizontal and vertical accountability, the rule of law and good governance; national human rights ombuds institutions as NHRIs; the investigatory, litigation, promotional and other powers of human rights and classicbased ombuds and their methods for applying international and domestic human rights law; ombuds institutions and the protection and promotion of international children's rights; national human rights ombuds additional mandates as OPCAT national preventive mechanisms, UN Convention on the Rights of Persons with Disabilities Article 33(2) framework mechanisms and EU national equality bodies; human rights ombuds and business and human rights; ombuds institutions, gender and women's rights; the European Ombudsman and human rights; national human rights ombuds and other ombuds models by...

See More

\section{Readership}

In addition to the ombudsman community this book will be of interest to practitioners, academics, students and others in the fields of international law, international and domestic human rights law, comparative law, political science and public administration.

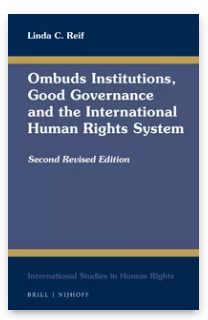

Pages: xvi, 812 pp.

Language:

English

Subjects:

Human Rights, Human Rights and

Humanitarian

Law

Publisher: Brill | Nijhoff

Series:

International

Studies in

Human Rights,

Volume: 133

E-Book (PDF)

Released online:

$27 \mathrm{Jul} 2020$

ISBN: 978-90-

04-27396-2

List price

USD \$167.00

Hardback

Publication date:

27 May 2004

ISBN: 978-90-

04-13903-9 


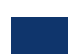


Biographical Note

Linda C. Reif is the Associate Dean (Graduate Studies) and CN Professor of International Trade at the Faculty of Law,

University of Alberta in Edmonton, Alberta, Canada.

For more information see brill.com

Order information: Order online at brill.com +44 330 333 0049 | customerservices@brill.com Submission information: brill.com/authors

Titles published by Brill | Fink, Brill | mentis or Brill | Schöningh: +49(o)71 5413279216 | brill@brocom.de 